\title{
KELIMPAHAN BAKTERI HETEROTROF DAN WATER QUALITY INDEX PADA KERAPATAN MANGROVE YANG BERBEDA DI DESA BEDONO, SAYUNG, DEMAK
}

\author{
Silvia Grandies Alva W, Sutrisno Anggoro*) dan Niniek Widyorini \\ Program Studi Manajemen Sumberdaya Perairan Departemen Sumberdaya Akuatik \\ Fakultas Perikanan dan Ilmu Kelautan Universitas Diponegoro \\ J1. Prof. Soedharto, SH Semarang, Jawa Tengah - 50275, Telp/Fax. +6224 7474698 \\ Email : grandies.alva@gmail.com
}

\begin{abstract}
ABSTRAK
Serasah mangrove yang jatuh di lantai mangrove akan di dekomposisi oleh mikroorganisme heterotrof yang memiliki kemampuan mendegradasi serasah mangrove. Tujuan dari penelitian ini adalah mengetahui kerapatan mangrove, total bakteri heterotrof perairan pada beberapa kerapatan mangrove, Indeks Kualitas Air (IKA) serta hubungan kerapatan mangrove dengan total bakteri heterotrof dan Indeks Kualitas Air (IKA) perairan di Desa Bedono, Demak. Penelitian ini menggunakan metode deskriptif, dengan mengukur parameter pendukung yaitu parameter fisika dan kimia, dan melakukan perhitungan kelimpahan bakteri heterotrof menggunakan metode TPC (Total Plate Count). Hasil pengamatan menunjukan bahwa kelimpahan bakteri heterotrof tinggi berkisar antara $(2.120-5.620) \times 10^{-6} \mathrm{Cfu} / \mathrm{ml} \mathrm{pada}$ saat pasang dan $760-4.840 \times 10^{-6} \mathrm{Cfu} / \mathrm{ml}$ pada saat surut.. Berdasarkan hasil penelitian dapat disimpulkan bahwa kerapatan mangrove pada Desa Bedono berkisar antara 900-2.400 pohon/Ha; kelimpahan bakteri hetrotrof di Desa Bedono berkisar antara 760x $10^{-6} \mathrm{Cfu} / \mathrm{ml}-5.620 \times 10^{-6} \mathrm{Cfu} / \mathrm{ml}$; Indeks Kualitas Air (IKA) yang didapatkan berkisar antara 33,1-46,93; terdapat hubungan yang berbanding lurus antara kelimpahan bakteri heterotrof dengan kerapatan mangrove, dan hubungan berbanding terbalik antara Indeks Kualitas Air (IKA), kelimpahan bakteri heterotrof dan kerapatan mangrove.
\end{abstract}

Kata Kunci: Bakteri Heterotrof, Kerapatan Mangrove, Desa Bedono, Indeks Kualitas Air

\section{ABSTRACT}

The mangrove litter that falls on the mangrove floor will be decomposed by heterotrophic microorganisms that have the ability to degrade the mangrove litter. This research is purposed to know the density of mangrove in Bedono, Demak; Looking for total heterotrophic bacteria in some mangrove densities in Bedono village, Demak; knowing Water Quality Index (IKA) in Bedono Village; know the relationship of mangrove density with total heterotrophic bacteria, and Water Quality Index (IKA) in Bedono Village, Demak. This study uses a descriptive method, by measuring the supporting parameters of physical and chemical parameters, and calculating the abundance of heterotrophic bacteria using TPC (Total Plate Count) method. The observed results show the high abundance of heterotrophic bacteria ranging between (2.120-5.620) $\times 10^{-6} \mathrm{Cfu} / \mathrm{ml}$ at high tide and 760-4.840 $\times 10^{-6} \mathrm{Cfu} / \mathrm{ml}$ at low tide. Based on the results of the research can be concluded that the mangrove density in Bedono village ranged between 900-2.400 trees/Ha; The Water Quality Index (IKA) that occurs is between 33,1-46,93; There is a direct relationship between the abundance of heterotrophic bacteria with mangrove density, and the inverse relationship between the Water Quality Index (IKA), abundance of heterotrophic bacteria and mangrove density.

Keywords: Heterotrophic Bacteria, Mangrove Density, Bedono Village, Water Quality Index

\section{*) Penulis Penanggungjawab}

\section{PENDAHULUAN}

Hutan mangrove merupakan hutan yang mempunyai peranan sebagai mata rantai perputaran unsur hara yang penting bagi organisme akuatik. Sumbangan terpenting hutan mangrove terhadap ekosistem perairan adalah lewat luruhan daunnya yang gugur berjatuhan ke dalam air. Luruhan daun mangrove merupakan sumber bahan organik yang terpenting dalam rantai makanan (food chain) di lingkungan perairan. Dalam rantai makanan, daun memegang peranan penting karena merupakan sumber nutrisi sebagai awal rantai makanan. Serasah daun mangrove yang jatuh di lantai mangrove secara biologis mengalami proses dekomposisi oleh mikroorganisme yang memiliki kemampuan mendegradasi jaringan daun. Mikroorganisme yang mampu mendegradasikan bahan organik menjadi bahan anorganik adalah bakteri heterotrof, di dalam lingkungan bakteri ini berfungsi sebagai dekomposer. Salah satu detritus penting 
yang perlu diketahui dalam ekosistem mangrove adalah bakteri heterotrof. Bakteri heterotrof dapat mendegradasi serasah mangrove menjadi zat yang dapat dimanfaatkan oleh mangrove maupun biota yang berasosiasi di dalam ekosistem mangrove. Kelimpahan bakteri heterotrof dapat dilihat dari jumlah bakteri yang ada pada perairan pada ekosistem mangrove. Aspek yang dapat diteliti lebih dalam adalah mengenai total bakteri heterotrof yang ada pada ekosistem mangrove terhadap kerapatan yang berbeda, baik rapat, sedang, maupun jarang.

Salah satu detritus penting yang perlu diketahui dalam ekosistem mangrove adalah bakteri heterotrof. Bakteri heterotrof dapat mendegradasi serasah mangrove menjadi zat yang dapat dimanfaatkan oleh mangrove maupun biota yang berasosiasi di dalam ekosistem mangrove. Kelimpahan bakteri heterotrof dapat dilihat dari jumlah bakteri yang ada pada perairan pada ekosistem mangrove. Aspek yang dapat diteliti lebih dalam adalah mengenai total bakteri heterotrof yang ada pada ekosistem mangrove terhadap kerapatan yang berbeda, baik rapat, sedang, maupun jarang.

Bakteri heterotrof, algae, dan protozoa merupakan mikroorganisme heterotrof yang mampu memanfaatkan bahan organik dan anorganik, yang ada pada lingkungan tempat tumbuhnya sebagai sumber nutrisi. Bakteri heterotrof memegang peranan utama pada penanganan limbah organik, sehingga limbah yang dihasilkan tidak mencemari lingkungan (Parwanayoni, 2008). Proses mikrobial yang dilakukan oleh bakteri heterotrof dapat dimanfaatkan untuk meningkatkan kualitas air dan mengurangi beban cemaran limbah yang ada pada mangrove.

Penelitan tentang hubungan kelimpahan bakteri heterotrof dengan kerapatan berbeda, telah dilakukan sebelumnya pada ekosistem lamun. Berdasarkan hasil penelitian Ariyanti et al., (2016), semakin rapat jumlah tegakan pada lamun maka semakin tinggi pula bakteri heterotrof yang menempel di daun lamun, dan sebaliknya, semakin sedikit kerapatan jumlah tegakan lamun maka akan semakin sedikit pula kelimpahan bakteri heterotrof yang menempel pada daun lamun. Hal ini menunjukan adanya hubungan antara kerapatan lamun dengan jumlah bakteri heterotrof. Berdasarkan penelitian tersebut akan dilakukan penelitian dengan topik yang sama tentang bakteri heterotrof, tetapi dengan lokasi yang berbeda yaitu di hutan mangrove, menjadi hubungan kelimpahan bakteri heterotrof perairan dengan kerapatan mangrove di Desa Bedono, Demak.

Belum banyaknya penelitian tentang bakteri heterotrof yang dilakukan membuat kurangnya informasi tentang hubungan total bakteri heterotrof pada tipe kerapatan mangrove yang berbeda. Berdasarkan hal tersebut maka perlu dikaji lebih dalam tentang total bakteri heterotrof yang terdapat pada ekosistem mangrove, dilihat dari kerapatan mangrove yang berbeda di perairan Desa Bedono, Demak, dan hasil yang didapat dapat dimanfaatkan sebagai rekomendasi pengelolaan hutan mangrove di Desa Bedono, Demak.

Tujuan penelitian ini antara lain adalah :

1. Mengetahui kerapatan mangrove pada lokasi sampling di Desa Bedono, Demak;

2. Mengetahui total bakteri heterotrof perairan pada kerapatan mangrove yang berbeda pada lokasi sampling di Desa Bedono, Demak;

3. Mengetahui Indeks Kualitas Air (IKA) perairan pada lokasi sampling di Desa Bedono, Demak;

4. Mengetahui hubungan kerapatan mangrove dengan total bakteri heterotrof dan Indeks Kualitas Air (IKA) perairan pada lokasi sampling di Desa Bedono, Demak.

\section{MATERI DAN METODE PENELITIAN}

\section{Materi}

Materi pada penelitian ini adalah mangrove dengan kerapatan yang berbeda dan faktor lingkungan di kawasan konservasi mangrove Desa Bedono, Kecamatan Sayung, Demak.

\section{Metode}

Menghitung kerapatan mangrove dengan menggunakan kuadran 10 x10 meter, dan mengambil sampel air pada masing-masing stasiun dengan kerapatan mangrove yang berbeda, yaitu stasiun dengan kerapatan mangrove jarang, sedang dan rapat pada saat pasang dan surut. Selain itu pada masing-masing stasiun juga diukur parameter fisika dan kimia yaitu kecerahan air, suhu air, kedalaman, kecepatan arus, $\mathrm{pH}$, kadar oksigen terlarut (DO), salinitas, nitrat, dan bahan organik.

Sampel air yang diperolehb kemudian dilakukan perhitungan kelimpahan bakteri dengan metode TPC (Total Plate Count) cawan sebar (spread plate) yang mengacu pada SNI 01-2332.3-2006. Sampel air diencerkan secara bertingkat dengan menggunakan air laut steril hingga pengenceran $10^{-6}$, kemudian sampel diinokulasi pada media TGY (Tryptone Glucose Yeast) dan diinkubasi menggunakan inkubator selama \pm 24 jam. Koloni bakteri yang tumbuh dihitung dan dimasukkan kedalam rumus sebagai berikut :

$$
\mathrm{A}=\frac{1.000 \times \sum \text { koloni } X \text { Pengenceran }}{\text { Vol. Inokulasi }}
$$

Keterangan :

$\mathrm{A}=$ kelimpahan bakteri (upk/ml)

upk $=$ unit pembentukan koloni $(\mathrm{cfu}=$ colony forming unit $)$.

\section{Analisis Data}

Analisis data dibantu dengan program SPSS Statistics 16. Untuk mengetahui hubungan antara kelimpahan bakteri dengan kerapatan mangrove yang berbeda digunakan uji Paired T-test, dan untuk mengetahui hubungan dan 
kekuatan hubungan antara kelimpahan bakteri heterotrof, kerapatan mangrove dan indeks kualitas air (IKA) menggunakan uji korelasi pearson.

\section{HASIL DAN PEMBAHASAN}

Keadaan Umum Lokasi

Lokasi pengambilan air sampel terletak pada daerah konservasi mangrove di Desa Bedono, Kecamatan Sayung, Demak. Desa Bedono terletak di Kecamatan Sayung, Kabupaten Demak. Kecamatan Sayung dibagi menjadi 16 desa. Desa Bedono, Desa Timbulsloko dan Desa Surodadi merupakan 3 desa yang terletak di daerah pesisir. Kecamatan Sayung merupakan daerah perairan yang di pengaruhi oleh fenomena rob dan abrasi, yang merupakan bagian dari sirkulasi pasang surut dan arus laut, yang selalu berubah sesuai dengan perubahan musim. Hal ini dikarenakan rata-rata ketinggian permukaan tanah di Kecamatan Sayung berada diantara ketinggian permukaan air surut terendah dan pasang tertinggi. Kecamatan Sayung termasuk dataran rendah yang memiliki topografi relatif datar, dengan ketinggian 3 meter diatas permukaan laut (Widada et al., 2012).

Berdasarkan hasil survei lapangan oleh Chafid et al., (2012), pada kawasan pesisir Desa Bedono, Kecamatan Sayung, Kabupaten Demak ditemukan tiga spesies mangrove di yang terdiri dari dua famili dan dua genus yang dari satu kelompok yang sama. Spesies mangrove yang banyak ditemukan di kawasan pesisir Desa Bedono, Kecamatan Sayung, Kabupaten Demak adalah Avicennia marina dan Rhizophora mucronata.

\section{Kerapatan Mangrove}

Hasil pengukuran kerapatan mangrove yang mengacu pada Keputusan Menteri Lingkungan Hidup nomor 201 Tahun 2004 disajikan pada Tabel 1 sebagai berikut :

Tabel 1. Hasil Perhitungan Kerapatan Mangrove Desa Bedono, Kecamatan Sayung, Demak

\begin{tabular}{ccccc}
\hline Stasiun & $\begin{array}{c}\text { Kerapatan } \\
(\text { Pohon/Ha) }\end{array}$ & $\begin{array}{c}\text { Diameter } \\
(\mathbf{c m})\end{array}$ & Kriteria Baku & $\begin{array}{c}\text { Komposisi Jenis } \\
\text { Mangrove }\end{array}$ \\
\hline I & 900 & $10,19-17,5$ & $\begin{array}{c}<1.000 \\
(\text { jarang) }\end{array}$ & Avicennia marina \\
II & 1.400 & $6,68-15,91$ & $\begin{array}{c}>000-<1.500 \\
(\text { sedang) }\end{array}$ & Avicennia marina \\
III & 2.400 & $6,05-17,5$ & $\begin{array}{c}>1.500 \\
\text { (rapat) }\end{array}$ & Avicennia marina \\
\hline
\end{tabular}

Berdasarkan hasil yang diperoleh, jenis mangrove yang ada pada lokasi penelitian di Desa Bedono, Kecamatan Sayung, Demak adalah jenis Avicennia marina, dengan diameter pohon yang berkisar antara 6,06-17,5 cm. Stasiun satu terdapat 900 tegakan/Ha dengan diameter berkisar antara 10,19-17,5 cm, termasuk dalam golongan jarang, stasiun 2 terdapat 1.400 tegakan/Ha dengan diameter berkisar antara 6,68-15,91 cm, termasuk dalam golongan sedang, dan stasiun tiga terdapat 2.400 tegakan/Ha dengan diameter berkisar antara 6,05-17,5 cm, termasuk dalam golongan rapat. Penggolongan kerapatan mangrove ini sesuai dengan Keputusan Menteri Lingkungan Hidup nomor 201 Tahun 2004 , yang menyatakan bahwa kerapatan pohon/Ha $>1.500$ termasuk dalam golongan sangat padat, kerapatan pohon/Ha $>1.000-<1.500$ termasuk dalam golongan sedang, dan kerapatan pohon/Ha $<1.000$ termasuk dalam golongan jarang.

Hubungan Kelimpahan Bakteri Heterotrof dengan Kerapatan Mangrove dan Indeks Kualitas Air

Hasil perhitungan kelimpahan bakteri heterotrof di Desa Bedono, Kecamatan Sayung, Demak dengan menggunakan metode TPC (Total Plate Count) disajikan pada Tabel 2 sebagai berikut :

Tabel 2. Hasil Perhitungan Kelimpahan Bakteri Heterotrof di Desa Bedono, Kecamatan Sayung, Demak

\begin{tabular}{cccc}
\multirow{2}{*}{ Ulangan ke- } & Stasiun & \multicolumn{2}{c}{ Jumlah Bakteri $\left.\left(\mathbf{x 1 0}^{-6}\right) \mathbf{( ~ C f u} / \mathbf{m l}\right)$} \\
\cline { 2 - 4 } & & Pasang & Surut \\
\hline \multirow{2}{*}{1} & I & 2.500 & 2.520 \\
& II & 4.960 & 3.540 \\
& III & 5.620 & 4.340 \\
2 & I & 1.520 & 760 \\
& II & 2.120 & 1.320 \\
& III & 5.400 & 4.840 \\
3 & I & 1.580 & 800 \\
& II & 4.520 & 1.720 \\
& III & 4.740 & 2.120
\end{tabular}

hasil pengukuran parameter fisika dan kimia pada setiap stasiun didapatkan hasil sebagai berikut: 
Tabel 3. Hasil Pengukuran Parameter Fisika dan Kimia

\begin{tabular}{|c|c|c|c|c|c|c|c|c|}
\hline \multirow{2}{*}{ Stasiun } & \multirow{2}{*}{ Variabel } & & \multicolumn{3}{|c|}{ Ulangan } & \multirow{2}{*}{ Mean } & \multirow{2}{*}{ SD } & \multirow{2}{*}{$\mathbf{K V}$} \\
\hline & & & I & II & III & & & \\
\hline $\mathrm{I}$ & \multirow{6}{*}{ Kedalaman $(\mathrm{cm})$} & & 25 & 22 & 23 & \multirow{3}{*}{23,56} & \multirow{3}{*}{1,42} & \multirow{3}{*}{6,05} \\
\hline II & & $\mathrm{P}$ & 23 & 24 & 25 & & & \\
\hline III & & & 24 & 25 & 21 & & & \\
\hline $\mathrm{I}$ & & \multirow{3}{*}{$\mathrm{S}$} & 20 & 19 & 20 & \multirow{3}{*}{18,89} & \multirow{3}{*}{1,27} & \multirow{3}{*}{6,72} \\
\hline II & & & 18 & 18 & 18 & & & \\
\hline III & & & 19 & 21 & 17 & & & \\
\hline I & \multirow{6}{*}{ Kecepatan Arus (m/s) } & \multirow{3}{*}{$\mathrm{P}$} & 0,31 & 0,35 & 0,24 & \multirow{3}{*}{0,30} & \multirow{3}{*}{0,06} & \\
\hline II & & & 0,42 & 0,24 & 0,27 & & & 21,34 \\
\hline III & & & 0,29 & 0,22 & 0,32 & & & \\
\hline $\mathrm{I}$ & & & 0,32 & 0,31 & 0,42 & & & \\
\hline II & & $\mathrm{S}$ & 0,34 & 0,33 & 0,31 & 0,32 & 0,05 & 15,40 \\
\hline III & & & 0,25 & 0,26 & 0.32 & & & \\
\hline I & & & 29 & 31 & 29 & & & \\
\hline II & & $\mathrm{P}$ & 29 & 29 & 30 & 29,44 & 0,73 & 2,47 \\
\hline III & Suhu $\left({ }^{\circ} \mathrm{C}\right)$ & & 29 & 30 & 29 & & & \\
\hline I & sunu (c) & & 29 & 29 & 30 & & & \\
\hline II & & S & 29 & 30 & 28 & 29,22 & 0,67 & 2,28 \\
\hline III & & & 29 & 29 & 30 & & & \\
\hline I & & & 7 & 7 & 7 & & & \\
\hline II & & $\mathrm{P}$ & 8 & 8 & 8 & 7,22 & 0,83 & 11,54 \\
\hline III & & & 8 & 6 & 6 & & & \\
\hline I & $\mathrm{pH}$ & & 7 & 7 & 7 & & & \\
\hline II & & $\mathrm{S}$ & 8 & 8 & 8 & 7,44 & 0,73 & 9,76 \\
\hline III & & & 8 & 6 & 8 & & & \\
\hline I & & & 25 & 20 & 25 & & & \\
\hline II & & $\mathrm{P}$ & 25 & 22 & 24 & 24,11 & 1,90 & 7,88 \\
\hline III & & & 25 & 25 & 26 & & & \\
\hline I & Salınitas (\%o) & & 24 & 25 & 25 & & & \\
\hline II & & S & 25 & 25 & 26 & 24,78 & 0,83 & 3,36 \\
\hline III & & & 23 & 25 & 25 & & & \\
\hline Lanjutan & el 3. Hasil Pengukuran I & mete & ika dan $\mathrm{K}$ & & & & & \\
\hline & & & & Ingan & & & & \\
\hline Stasiun & Variabel & & I & II & III & Mean & SD & $\mathbf{K V}$ \\
\hline $\mathrm{I}$ & & & 2,44 & 2,92 & 2,20 & & & \\
\hline II & & $\mathrm{P}$ & 2,13 & 2,12 & 2,34 & 2,47 & 0,37 & 14,87 \\
\hline III & & & 2,53 & 3,20 & 2,36 & & & \\
\hline I & DU (ppm) & & 3,40 & 2,76 & 2,56 & & & \\
\hline II & & $\mathrm{S}$ & 3,24 & 3,68 & 3,20 & 3,04 & 0,36 & 11,98 \\
\hline III & & & 2,88 & 2,84 & 2,76 & & & \\
\hline $\mathrm{I}$ & & & 0,95 & 0,86 & 0,91 & & & \\
\hline II & & $\mathrm{P}$ & 2,44 & 0,66 & 1,10 & 1,63 & 1,21 & 73,87 \\
\hline III & Nitrat $(\mathrm{mo} / \mathrm{I})$ & & 3,12 & 0,79 & 3,92 & & & \\
\hline I & Nitrat (mg/L) & & 1,38 & 1,14 & 1,18 & & & \\
\hline II & & S & 1,21 & 1,66 & 0,91 & 1,47 & 0,62 & 42,46 \\
\hline III & & & 1,69 & 2,98 & 1,08 & & & \\
\hline $\mathrm{I}$ & & & 31,63 & 25,31 & 27,91 & & & \\
\hline II & & $P$ & 33,01 & 25,31 & 28,19 & 30,06 & 3,88 & 12,91 \\
\hline III & Rahan Oroanik (mo/I) & & 34,38 & 36,03 & 28,74 & & & \\
\hline $\mathrm{I}$ & Banan urganik (mg/L) & & 27,78 & 26,41 & 27,91 & & & \\
\hline II & & S & 27,23 & 25,58 & 27,08 & 28,71 & 4,139 & 14,42 \\
\hline III & & & 39,33 & 29,71 & 27,35 & & & \\
\hline
\end{tabular}

Keterangan : I : Mangrove dengan kerapatan jarang; II : Mangrove dengan kerapatan Sedang; III : Mangrove dengan kerapatan Rapat; P : Pasang; S : Surut; SD : Standar Deviasi; KV : Koefisien Korelasi; hasil pengukuran kecerahan pada seluruh stasiun adalah tak hingga $(\infty)$. 
Hasil pengukuran parameter fisika dan kimia tersebut kemudian digunakan untuk menghitung indeks kualitas air (IKA) dengan menggunakan rumus NFS-WQI (National Sanitation Foundation- Water Quality Index) dan didapatkan hasil sebagai berikut :

Tabel 4. Hasil Perhitungan Indeks Kualitas Air (IKA) di Desa Bedono, Kecamatan Sayung, Demak.

\begin{tabular}{cccccc}
\hline \multirow{2}{*}{ No } & \multirow{2}{*}{ Sampling } & \multirow{2}{*}{ Stasiun } & \multicolumn{2}{c}{ Pasang-Surut } & \multirow{2}{*}{ Pustaka } \\
\cline { 4 - 5 } & & 1 & Pasang & Surut & \\
\multirow{2}{*}{1} & \multirow{2}{*}{06 Maret 2017 } & 2 & 46,63 & 46,93 & \\
& & 3 & 44,98 & 45,97 & \\
\hline \multirow{2}{*}{2} & \multirow{2}{*}{13 Maret 2017 } & 1 & 43,83 & 45,44 & \\
& & 2 & 46,40 & 46,63 & 26-50: Buruk \\
& & 3 & 45,67 & 45,51 & (Tyagi, 2013) \\
\multirow{2}{*}{3} & \multirow{2}{*}{20 Maret 2017 } & 1 & 38,78 & 37,33 & \\
& & 2 & 46,63 & 46,40 & \\
\hline
\end{tabular}

Kualitas lingkungan dipengaruhi oleh kerapatan dari mangrove. Lokasi dengan tegakan mangrove yang rapat nilai Indeks Kualitas Air (IKA) yang didapatkan berkisar antara didapatkan cenderung lebih tinggi yaitu berkisar antara 46,40-46,93 termasuk dalam kategori buruk. Stasiun dua dengan kerapatan mangrove sedang nilai Indeks Kualitas Air (IKA) yang didapatkan berkisar antara 44,98-46,20 termasuk dalam kategori buruk, dan nilai Indeks Kualitas Air (IKA) paling rendah terdapat pada stasiun tiga yaitu berkisar antara 37,33-45,44 yang temasuk dalam kategori buruk. Hal ini dikarenakan lokasi dengan tegakan mangrove yang rapat menghasilkan serasah yang lebih banyak, serta daun yang rimbun menutup masuknya sinar matahari yang berperan penting dalam proses fotosintesis, menyebabkan proses fotosintesis berkurang, dan banyak oksigen yang digunakan dalam proses dekomposisi serasah menjadi bahan organik. Oksigen yang rendah juga akan mempengaruhi $\mathrm{pH}$ air, dan perubahan parameter fisika dan kimia yang lain, hal ini diduga menjadikan nilai Indeks Kualitas Air (IKA) pada Desa Bedono, Kecamatan Sayung, Demak menjadi rendah. Menurut Khattab dan Merkel (2012), bakteri heterotrof memiliki keterkaitan yang erat dengan parameter kualitas air, khususnya fosfat, karbon organik terlarut (DOC), karbon anorganik total (TIC), salinitas, dan $\mathrm{pH}$.

Kadar oksigen yang rendah yaitu berkisar antara 2,12-3,68 ppm, nilai tersebut berada di bawah baku mutu air laut untuk biota air untuk mangrove yaitu $>5 \mathrm{ppm}$. Rendahnya kadar oksigen terlarut dikarenakan kadar bahan organik yang tinggi antara 25,308-39,329 mg/l, oksigen terlarut digunakan oleh bakteri heterotrof untuk mengoksidasi bahan organik yang kemudian akan dimanfaatkan oleh biota lain. Hasil pengukuran $\mathrm{pH}$ air pada tiga stasiun sampling dengan kerapatan mangrove yang berbeda, yaitu jarang, sedang dan rapat didapatkan nilai yang berkisar antara 6-8, $\mathrm{pH}$ pada perairan ini sedikit lebih tinggi dengan $\mathrm{pH}$ optimal untuk kehidupan bakteri yaitu antara 6,5-7,5. Menurut Pelczar dan Chan (2008), pH optimum untuk bakteri berkisar antara 6,5-7,5. Beberapa spesies dapat tumbuh dalam keadaan sangat asam, atau sangat alkalin, hal ini diperkuat pula oleh pernyataan dari Isyuniarto dan Purwadi, (2007), bakteri dapat hidup pada pH 6-9, namun pH yang optimum untuk pertumbuhan bakteri berkisar antara 6,5-7,5. Menurut Patty (2014), kandungan nitrat secara alamiah berasal dari perairan itu sendiri, yaitu melalui proses-proses penguraian pelapukan ataupun dekomposisi tumbuh-tumbuhan dan sisa-sisa organisme mati, selain itu juga tergantung pada keadaan sekeliling, diantaranya sumbangan dari daratan melalui sungai yang bermuara ke perairan, seperti buangan limbah ataupun sisa pakan yang dengan adanya bakteri, terurai menjadi zat hara dan dalam proses penguraiannya banyak membutuhkan oksigen.

Kadar bahan organik $\left(\mathrm{KMNO}_{4}\right)$ yang didapatkan juga mempengaruhi pertumbuhan bakteri heterotrof, hal ini dikarenakan bahan organik merupakan sumber makanan bagi bakteri heterotrof. Kadar bahan organik tertinggi berada pada stasiun 3 dengan kerapatan mangrove rapat, yaitu sebesar 39,329 $\mathrm{mg} / \mathrm{l}$, dan yang paling rendah terdapat pada stasiun satu dengan kerapatan mangrove jarang, yaitu sebesar 25,308 mg/l. Menurut Widhitama et al., (2016), kerapatan pada mangrove mempengaruhi dari hasil produksi serasah dan laju dekomposisi, dimana semakin rapat tegakan mangrove, maka serasah yang dihasilkan akan semakin banyak, dan laju dekomposisi juga akan semakin cepat. Hasil pengukuran tersebut menunjukkan bahwa semakin rapat kerapatan mangrove maka akan semakin tinggi produksi serasah dan bahan organik, yang kemudian berpengaruh pula terhadap kelimpahan bakteri heterotrof yang ada pada air. Semakin rapat tegakan mangrove maka semakin banyak pula kelimpahan bakteri heterotrof yang ada pada daerah tersebut dikarenakan sumber makanan bakteri heterotrof yang melimpah, dan diiringi dengan menurutnnya kualitas air akbat proes dekomposisi yang terjadi.

Hubungan antara kelimpahan bakteri heterotrof dengan kerapatan mangrove dan Indeks Kualitas Air (IKA), diuji dengan menggunakan uji korelasi pearson sebagai berikut :

Gambar 1. Grafik Hubungan Bakteri Heterotrof (Cfu/ml) dengan Kerapatan (jumlah tegakan/Ha)

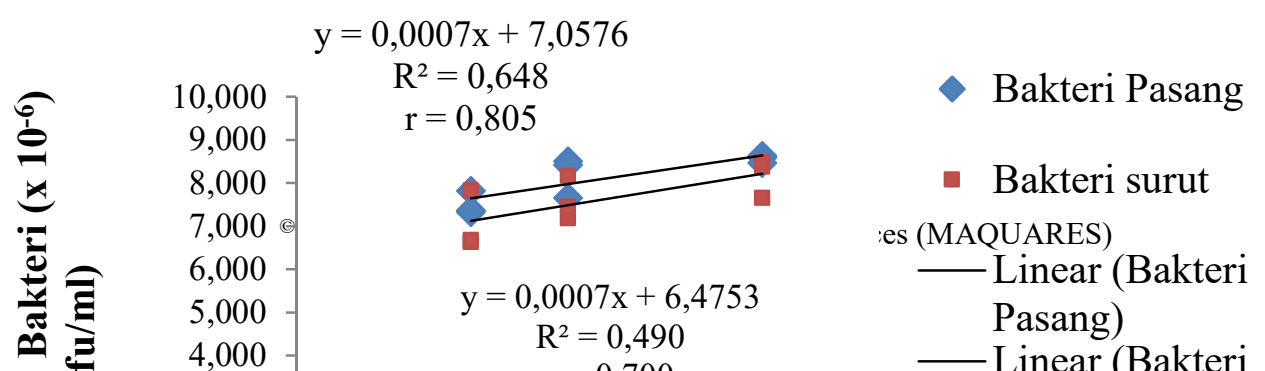


Berdasarkan Gambar 1. didapatkan nilai $\mathrm{R}^{2}$ atau koefisien determinasi menunjukkan hasil 0,648 pada bakteri pasang, 0,4903 pada bakteri surut, hal ini menunjukkan bahwa kelimpahan bakteri 64,8\% pada saat pasang dan $49,03 \%$ pada saat surut dipengaruhi oleh kerapatan mangrove yang ada, dan sisanya dipengaruhi oleh faktor lain. Nilai Pearson Coefficient yang didapatkan menandakan tingkat hubungan antara kerapatan mangrove dengan kelimpahan bakteri heterotrof sangat kuat. Menurut Mira (2013), interval koefisien korelasi nilai $r$ antara nilai 0,000- 0,199 menunjukkan tingkat hubungan yang sangat lemah; nilai 0,200-0,399 menunjukkan tingkat hubungan yang lemah; nilai 0,400-0,599 menunjukkan tingkat hubungan yang cukup kuat; nilai 0,600-0,799 menunjukkan tingkat hubungan yang kuat; dan nilai 0,800-1,00 menunjukkan tingkat hubungan yang sangat kuat antar variabel.

Hasil uji T-Test antara Indeks Kualitas Air (IKA) dengan Kerapatan Mangrove dan Kelimpahan Bakteri Heterotrof di sajikan dalam Tabel 5 sebagai berikut:

Tabel 5. Hasil Uji Paired Sample T-Test

\begin{tabular}{llrrrrrr}
\hline & \multicolumn{1}{c}{ No. Pasangan } & N & $\begin{array}{c}\text { Korelasi } \\
\text { Pearson }\end{array}$ & Sig. & t & df & $\begin{array}{c}\text { Sig. } \\
\text { (2 tailed) }\end{array}$ \\
\hline 1 & IKA \& Kerapatan_mangrove & 18 &,- 691 &, 002 & 9,991 & 17 &, 000 \\
2 & Bakteri \& Kerapatan_mangrove & 18 &, 714 &, 001 & 4,851 & 17 &, 000 \\
3 & Bakteri \& IKA & 18 &,- 612 &, 007 & 7,586 & 17 &, 000 \\
\hline
\end{tabular}

Tabel 6. Hasil Uji Beda

One-Sample Test

\begin{tabular}{|c|c|c|c|c|c|c|}
\hline & \multicolumn{6}{|c|}{ Test $V$ alue $=18$} \\
\hline & \multirow[b]{2}{*}{$\mathbf{t}$} & \multirow[b]{2}{*}{ df } & \multirow[b]{2}{*}{ Sig. (2-tailed) } & \multirow{2}{*}{$\begin{array}{c}\text { Mean } \\
\text { Difference }\end{array}$} & \multicolumn{2}{|c|}{$\begin{array}{l}\text { 95\% Confidence Interval of the } \\
\text { Difference }\end{array}$} \\
\hline & & & & & Lower & Upper \\
\hline Kerapatan_mangrove & 10,239 & 17 &, 000 & 1548,66667 & 1229,5623 & 1867,7711 \\
\hline
\end{tabular}

Hasil uji paired sample T-test didapatkan hasil nilai signifikansi lebih kecil dari 0,05, yaitu 0,00, yang berarti $\mathrm{H} 0$ ditolak dan H1 diterima, terdapat hubungan antara kerapatan mangrove yang berbeda dengan kelimpahan bakteri heterotorof. Hubungan tersebut didukung dengan hasil uji linieritas menunjukan nilai Significant Deviation from Linearity bakteri heterotrof pada saat pasang dan surut lebih besar dari 0,05 yaitu sebesar 0,261 dan 0,973 yang berarti terdapat hubungan yang berbanding lurus antara kelimpahan bakteri dengan kerapatan mangrove. Nilai $\mathrm{R}^{2}$ atau koefisien determinasi menunjukkan hasil 0,648 pada bakteri pasang dan 0,4903 pada bakteri surut. Hasil uji Pearson Correlation menunjukan kekuatan hubungan dari kerapatan mangrove yang berbeda dengan kelimpahan bakteri heterotrof yang kuat yaitu sebesar 0,714. Koefisien kontingensi menunjukkan bahwa kelimpahan bakteri heterotrof memiliki hubungan yang signifikan dengan kerapatan mangrove sebesar 0,15 . Hasil uji beda antar kerapatan mangrove didapatkan hasil signifikansi sebesar 0,000 yang berarti terdapat perbedaan antarakerapatan mangrove rapat, sedang dan jarang.

Berdasarkan hasil yang didapatkan semakin rapat jumlah tegakan mangrove maka semakin tinggi pula kelimpahan bakteri heterotrof yang ditemukan, hal ini menunjukkan bahwa terdapat hubungan yang berbanding lurus antara kerapatan mangrove dengan kelimpahan bakteri heterotrof. Kelimpahan bakteri yang berbanding lurus dengan kerapatan mangrove dikarenakan semakin rapat mangrove, maka bahan organik yang merupakan sumber makanan dari bakteri heterotrof tersebut juga akan semakin banyak, hal ini diduga yang menyebabkan kelimpahan bakteri heterotrof pada kawasan dengan mangrove yang rapat akan semakin banyak. Bakteri heterotrof memperoleh makanan berupa zat organik dari lingkungan karena tidak dapat menyusun sendiri zat organik yang dibutuhkannya. Zat-zat organik diperoleh dari sisa organisme lain, sampah, atau zat-zat yang terdapat di dalam tubuh organisme lain, apabila pada 
perairan banyak terdapat bahan organik maka pertumbuhan bakteri heterotrof akan melebihi pertumbuhan bakteri nitrifikasi (Notowinarto, 2015).

Berdasarkan hasil perhitungan indeks kualitas air yang dilakukan, didapatkan kualitas perairan yang ada pada Desa Bedono, Kecamatan Sayung, Demak berada pada kategori buruk hingga rata-rata. Pada stasiun satu, mangrove dengan kerapatan jarang hasil IKA yang didapatkan cenderung lebih tinggi yaitu berkisar antara 50,9-51,14 termasuk dalam kategori rata-rata. Stasiun dua dengan kerapatan mangrove sedang nilai IKA yang didapatkan berkisar antara 49,29-50,52 termasuk dalam kategori buruk, dan nilai IKA paling rendah terdapat pada stasiun tiga yaitu berkisar antara 36,05-49,75 yang temasuk dalam kategori buruk. Menurut Tyagi (2013), kualitas perairan dikatakan buruk apabila nilai IKA yang didapatlkan berkisar antara 26-50, dan rata-rata apabila nilai IKA yang didapatkan berkisar antara 51-70. Pada minggu kedua IKA yang didapatkan pada saat pasang maupun surut berada pada kategori rata-rata. Minggu ketiga IKA yang didapatkan pada saat pasang maupun surut termasuk dalam kategori buruk, hal ini sejalan dengan parameter fisika dan kimia yang diukur. Kategori buruk tersebut dipengaruhi oleh hasil pengukuran parameter fisika dan kimia yang rendah.

\section{KESIMPULAN}

Kesimpulan yang diperoleh dari penelitian ini adalah sebagai berikut :

1. Kerapatan mangrove yang ada di Desa Bedono, Kecamatan Sayung, Demak tertinggi adalah 2.400 tegakan/Ha, dan yang terendah adalah 900 tegakan/Ha.

2. Kisaran total bakteri heterotrof yang ada di Desa Bedono, Kecamatan Sayung, Demak yang tertinggi pada pengenceran $10^{-6}$ adalah $760 \mathrm{Cfu} / \mathrm{ml}-5.620 \mathrm{Cfu} / \mathrm{ml}$.

3. Nilai Indeks Kualitas Air yang didapatkan di desa Bedono, Kecamatan Sayung, Demak berkisar antara 36,0551,44 , yang tergolong dalam kategori buruk hingga rata-rata.

4. Kelimpahan bakteri heterotrof dengan kerapatan mangrove memiliki hubungan yang kuat dan berbanding lurus antara kelimpahan bakteri heterotrof dengan kerapatan mangrove, semakin tinggi kerapatan mangrove maka semakin banyak kelimpahan bakteri heterotrof, sedangkan IKA dengan kelimpahan bakteri heterotrof dan kerapatan mangrove memiliki hubungan yang berbanding terbalik.

\section{UCAPAN TERIMAKASIH}

Tulisan ini merupakan bagian dari laporan penelitian. Penulis mengucapkan terimakasih kepada keluarga, teman-teman MSP 2013, dan semua pihak yang selalu mendukung dan membantu dalam proses penyusunan laporan penelitian ini.

\section{DAFTAR PUSTAKA}

Ariyanti, V. N., Supriharyono, N. Widyorini. 2016. Hubungan Kerapatan Lamun dengan Kelimpahan Bakteri Heterotrof di Perairan Pantai Kartini Kabupaten Jepara. Diponegoro Journal of Maquares, 5(4):142-149.

Chafid, M. A., R. Pribadi, A. Anugroho. 2012. Kajian Perubahan Luas Lahan Mangrove di Desa Bedono Kecamatan Sayung Kabupaten Demak Menggunakan Citra Satelit Ikonos Tahun 2004 dan 2009. Journal of Marine Research, 1(2):167-173.

Isyuniarto, P.A. 2007. Pengaruh pH dan Oksidan Ozon Terhadap Jumlah Bakteri Coliform pada Limbah Rumah Sakit (Studi Kasus Limbah RSUD Kota Yogyakarta). Prosiding PPI - PDIPTN 2007.

Khattab , M. F. O., B. J. Merkel. 2012. Distribution of Heterotrophic Bacteria and Water Quality Parameters of Mosul Dam Lake, Northern Iraq. WIT Transactions on Ecology and The Environment, 16(9):195-207.

Mira. 2013. Performance of Ship Assistance Program for Fisheries. Jurnal Ekonomi Pembangunan, 14(2):180-191.

Notowinarto, F. Agustina. 2015. Populasi Bakteri Heterotrof di Perairan Pulau Bulang Batam. Jurnal Pendidikan Biologi Indonesia, 1(3):334-342.

Parwanayoni, N. M. S. 2008. Pergantian Populasi Bakteri Heteretrof, Algae, dan Protozoa, di Lagoon BTDC Unit Penanganan Limbah Nusa Dua Bali. Jurnal Bumi Lestari, 8(2):182.

Patty, S.I. 2014. Karakteristik Fosfat, Nitrat dan Oksigen Terlarut di Perairan Pulau Gangga dan Pulau Siladen, Sulawesi Utara. Jurnal Ilmiah Platax, 2(2):75.

Pleczar, M. J. Jr., E. C. S. Chan. 2008. Dasar-Dasar Mikrobiologi 1. Penerbit UI Press, Jakarta.

Tyagi S, B. Sharma, P. Singh, R. Dobhal. 2013. Water Quality Assesment in Terms of Water Quality Index. American Journal of Water Resources, 1(3):34-38.

Widada, S., B. Rochaddi, H. Endrawati. 2012. Pengaruh Arus terhadap Genangan Rob di Kecamatan Sayung Kabupaten Demak. Buletin Oseanografi Marina, 1:31-39.

Widhitama, S., P. W. Purnomo, A. Suryanto. 2016. Produksi dan Laju Dekomposisi Serasah Mangrove Berdasarkan Tingkat Kerapatannya di Delta Sungai Wulan, Demak, Jawa Tengah. Diponegoro Journal of Maquares, 5(4):311-319. 